удк $\quad$ 34:929 Перић Ж.

94(497.11)"1941/1944"

DOI https://doi.org/10.31212/tokovi.2019.3.mil.127-150

Оригинални научни рад

Примљен: 3. 9. 2019.

Прихваћен: 19. 9. 2019.

Nataša MILIĆEVIĆ

Institute for Recent History of Serbia, Belgrade

natasa.milicevic@mts.rs

\title{
Always in the Minority: Živojin Perić in Occupied Serbia 1941-1944*
}

\begin{abstract}
The paper analyzes the activities and views of Živojin Perić, PhD, a distinguished intellectual of pre-war Yugoslavia, during the Nazi occupation of Serbia. Although the paper focuses on his views and opinions regarding the war, it also includes his pre-war opinions and convictions on various political and social issues in order to present their continuity or lack thereof.

Key words: Serbia, World War II, German Occupation, Živojin Perić, Collaboration
\end{abstract}

Živojin Perić was an unusual figure in Serbian history, primarily its intellectual history. From his first forays into public and scientific life at the turn of the $20^{\text {th }}$ century, through the end of World War II, he stood out with his original and in many ways audacious political views and activities. This often meant he was out of and against the mainstream of Serbian politics of his time. For this reason, it could be said that he was almost always in the minority, opposing the opinions of the majority. To begin with, it should perhaps be noted that this distinguished legal expert, pedagogue, and writer was also a conservative and an Austrophile in the Kingdom of Serbia, leaning toward socialist ideas (Christian socialism), and that he was a proponent of a federalist Yugoslavia. It should also

* This article has been written within the framework of the scholarly project Serbs and Serbia in the Yugoslavian and International Context: Internal Development and Position in the European/Global Community (№ 47027), financed by the Ministry of Education, Science and Technological Development of the Republic of Serbia. 
be mentioned that he supported the work of Milan Nedić's cabinet under Nazi occupation. ${ }^{1}$ This somewhat validates the opinion held by many contemporary researchers that he often ended up being "on the wrong side of history." ${ }^{2}$ This is probably the reason why he was not sufficiently researched as an intellectual during the time of socialist Yugoslavia. ${ }^{3}$ Historiography mentions Živojin Perić only superficially, and usually within the framework of papers dealing with larger issues, events, or occurrences in the first half of the $20^{\text {th }}$ century. ${ }^{4}$ There have been attempts to examine

1 Živojin M. Perić (1868-1953), lawyer and Member of Parliament, was a longstanding professor of civil law at the Faculty of Law in Belgrade. He graduated from the Faculty of Law in Paris in 1891. He spent some time working in public institutions as a scrivener and judge. He began his teaching career in 1898 when he was named associate professor, and ended it in 1938 when he retired. He also served as the dean of the Faculty of Law $(1908 / 09,1912 / 13,1913 / 14,1914 / 19)$, with a break during World War I. He actively practiced politics before the war. He was a member of the main board of the Progressive Party from 1906 and a Member of Parliament from 1908 to 1912 . He started the magazine called Nedeljni pregled (The Weekly Overview) which expounded on conservative opinions. He founded the Conservative Party in 1914 with a group of like-minded individuals. It was a small party without much influence. He lived in Belgrade through both world wars. He was a Germanophile, so he collaborated with the Austrian-Hungarian occupier during World War I, and did the same with the German occupier and Milan Nedićs government during World War II. He published around 400 papers from different areas of the legal science. He was a corresponding member of the Serbian Royal Academy (from 1905), but he was not selected as a full member and he did not partake in the work of the Academy. He received an honorary doctorate from the University of Lyon in 1933 and the University of Belgrade in 1934. He was awarded the Order of Saint Sava, $3^{\text {rd }}$ Grade, the Order of Prince Danilo, $3^{\text {rd }}$ Class and the Order of the Cross of Takovo, $5^{\text {th }}$ Class (Драгомир Бонџић, „Живојин М. Перић“, Српски биографски речник, (mscr.); Др. Драг. Бл. Кечкић, Жив. П. Јовановић, „Биографија и библиографија Живојина Перића“, Правна мисао 11-12/1937, 621-649).

2 Марко Божић, „Задруга као судбина: Живојин Перић од Стублина до Београда и опет назад“, in: Живојин Перић, Задружно право по Грађанском законику Краљевине Србије, (Београд: Српско адвокатско друштво, ЈП „Службени гласник“, 2017), 15.

3 It seems that all this did not pose an obstacle to being asked to give opinions on certain texts, even after he left for Switzerland after the war. Milan Bartoš, his student, mentions that Perić analysed the text of the Law on the insignificance of legal regulations (February 1945) and that the study he wrote "made it rather difficult to prove the reciprocity of the existence of legal institutions in Yugoslavia" (Милан Бартош, „In Memoiriam: Живојин М. Перић (1868-1953)“, Анали Правног факултета у Београду, јануар-март 1954, 120).

4 Милош Ковић, „Либерализам“, Срби 1903-1914: Историја идеја, ур. Милош Ковић, (Београд: Clio, 2015), 153-201; Милош Ковић, „Национализам“, Срби 19031914, 202-269; Слободан Антонић, „Слика једног доба“, Срби 1903-1914, 763850; Александар Стојановић, Идеје, политички пројекти и пракса владе Милана Недића, (Београд: ИНИС, 2015); Latinka Perović, Dominantna i neželjena elita. Beleške o intelektualnoj i političkoj eliti u Srbiji XX-XXI vek, (Beograd: Dan Graf, Novi 
his political ideas in full. ${ }^{5}$ His life and work were naturally taken into consideration much more by legal science. Major papers devoted to his legal and political thinking have also been written. ${ }^{6}$ However, not even legal sci-

Sad: Javna medijska ustanova Radio-televizija Vojvodine, 2015); Михаило Војводић, Стојан Новаковић у служби националних и државних интереса, (Београд: Српска књижевна задруга, 2012); Dragomir Bondžić, Beogradski univerzitet 1944-1952, (Beograd: ISI, 2004); Српски цивилни/културни план владе Милана Недића, ур. Александар Стојановић, (Београд: ИНИС, 2012); Божица Б. Младеновић, Град у аустроугарској окупационој зони у Србији од 1916. до 1918. године, (Београд: Чигоја штампа, 2000); Андреј Митровић, „Надрастање пораза и подела“, Историја српског народа VI-2, (Београд: Српска књижевна задруга, 1994); Андреј Митровић, Србија у Првом светском рату, (Београд: Српска књижевна задруга, 1984); Љубинка Трговчевић, Научници Србије и стварање југословенске државе 1914-1920, (Београд: Народна књига, Српска књижевна задруга, 1987); Milosav Janićijević, Stvaralačka inteligencija međuratne Jugoslavije, (Beograd: Institut društvenih nauka - Centar za sociološka istraživanja, 1984).

5 Велимир Матковић, „Политичка мисао Живојина Перића“, (магистарски рад, Универзитет у Београду, Правни факултет, Београд, 2013); Olga Popović-Obradović, „Živojin Perić između liberalizma i konzervativizma“, Liberalna misao u Srbiji. Prilozi istoriji liberalizma od kraja XVIII do sredine XX veka, ur. Jovica Trkulja, Dragoljub Popović, (Beograd: Centar za unapređivanje pravnih studija Friedrich Naumann Stiftung, 2001), 317- 346; Бранко Надовеза, Политичка мисао Живојина Перића, (Београд: Институт за политичке студије, 2005).

6 Tomica Delibašić, „Osvrt na misao Živojina Perića, klasika prava“, Pravni život 12/2013, 503-516; Jelena Ćeranić, „Ideja Evropskog državnog saveza u delima profesora Živojina M. Perića", Aktuelna pitanja savremenog zakonodavstva, Zbornik radova sa Savetovanja pravnika 12-16. jun 2013, Budva, (Beograd: Savez udruženja pravnika Republike Srbije i Republike Srpske, 2013), 235-249; Jovica Trkulja, „Ispravljanje nepravde. Povodom 140. godišnjice rođenja Živojina Perića“, Hereticus 3-4/2008, 319-328; Александар Миљковић, „Погледи Живојина М. Перића на породичну задругу у Србији: прилог критици Перићевог схватања породичне задруге као комунистичке установе“, Анали Правног факултета у Београду, 1/2005, 93-112; Љубица Кандић, Јелена Даниловић, Историја Правног факултета у Београду 1808-1905, прва књига (Београд: Завод за уџбенике и наставна средства, 1997); Љубица Кандић, Историја Правног факултета у Београду 1905-1941, друга књига, том I-II, (Београд: Завод за уџбенике и наставна средства, 2002); Љубица Кандић, Историја Правног факултета у Београду 1941-1945, књ. 3, (Београд: Завод за уџбенике и наставна средства, 2005); Александар Миљковић, „Схаватње Живојина Перића о патријахалним породичним задругама“, Сто педесет година од доношења Српског грађанског законика (1844-1994): зборник радова са научног скупа одржаног 23. и 24. маја 1994, ур. Миодраг Јовичић, (Београд: САНУ, 1996), 351-359; Јовица Тркуља, „Политичке студије Живојина Перића“, Научно наслеђе Правног факултета у Београду 1841-1941, реферати са симпозијума одржаног 9. и 10. априла 1992, ур. Стеван Врачар, Јовица Тркуља, (Београд: Правни факултет у Београду, 1994), 399-409; Slobodan Perović, „Delo Živojina Perića - paradigma kulture prava“, Pravni život, No. 11-12/1993, VII-XX; Олга Поповић-Обрадовић, Парламентаризам у Србији 1903-1914, (Београд: Јавно предузеће Службени лист CPJ, 1998); Slobodan Perović, „Živojin Perić - život i delo“, Pravni život XXXVII, 1 (1987), 111-124; Miroljub Simić, „Teorija tumačenja prava Živojina M. Perića“, Zbornik radova Pravnog fakulteta u Nišu 19/1979, 319-336; Miroljub Simić, „Teorija 
ence has paid enough attention to him, considering his importance in the history of law. This is true of all the periods and phases of his intellectual and political work, particularly in the period of Nazi occupation, which will be discussed later. That said, the importance of Živojin Perić was nevertheless acknowledged by his contemporaries. This is substantiated by the opinions of several of his colleagues, esteemed professors of law, recorded at the end of 1937 and in 1938 on the occasion of his $70^{\text {th }}$ birthday and the conclusion of his teaching career. ${ }^{7}$ Živojin Spasojević thought Perić "seemed like an encyclopedist" ${ }^{\prime}$ because of his involvement in all the areas of law, while Slobodan Jovanović stated that he possessed the courage to express his opinion ("the valor of his opinion"), regardless of whether or not it would be appreciated. ${ }^{9}$ Similar thoughts were expressed by other distinguished individuals. Velizar Mitrović pointed out his "depth of understanding, originality, and courage," especially with regard to his analysis of international politics in the interwar period..$^{10}$ On the other hand, upon considering his conservative past, Jaša Prodanović stated that Perić's political thinking and activism were marked by "a strong commitment to his convictions and the courage to defend them without fear of public opinion." ${ }^{11}$ Although ideologically opposed to Perić, Jaša Prodanović also commended the fact that he "never wanted politics to elevate his status, make him wealthy, or satisfy his ego". Prodanović noted that he did not "rub elbows in court hallways, or sweet-talk the electorate." ${ }^{\prime 2}$ In addition to this, Jaša Prodanović also praised Perić's readiness to state his opinion regard-

tumačenja prava Živojina M. Perića (nastavak)“, Zbornik radova Pravnog fakulteta $u$ Nišu 19/1980, 369-380.

7 On January $16^{\text {th }}, 1938$, Živojin Perić turned seventy years of age. At that time, he had been teaching at the Faculty of Law for forty years and carrying out scientific work for almost fifty. At first, his associates, colleagues and friends had planned on expressing their reverence by publishing a tribute. They gave this idea up because Perić himself was against it. However, they decided to still discuss the various aspects of his person and his professional, intellectual and political engagements in the form of short papers published in legal journals at the end of 1937 and the beginning of 1938. (More in: Архив за правне и друштвене науке 1-2/1938; Правна мисао 1112/1937; Правосуђе 1-2/1938).

8 Живојин Спасојевић, „Живојин Перић као цивилиста“, Архив за правне и друштвене науке 1-2/1938, 12.

9 Слободан Јовановић, „Живојин Перић о владалачкој власти“, Архив за правне и друштвене науке 1-2/1938, 8.

10 Велизар Митровић, „О седамдесетогодишњици др Живојина Перића, редовног професора Правног факултета“, Архив за правне и друштвене науке 1-2/1938, 5.

11 Јаша М. Продановић, „Политика Живојина Перића“, Правна мисао 11-12/1937, 483.

12 Ibid., 484. 
ing the internal organization of the Yugoslav state, even during the 1930s and the internal political and national crisis of that time. This opinion of his was once again opposed to the majority opinion and closer to the opposition's federalist concepts. ${ }^{13}$ Unlike many like-minded intellectuals, he defended the idea of the Yugoslav federal state during the entire interwar period, as evidenced by some researchers. ${ }^{14}$ However, it wasn't only the distinguished contemporaries from his homeland that testified to his importance. ${ }^{15}$ Ž. Perić was also recognized in international academic circles. He was a member of several legal societies and a recipient of honorary doctorates from several universities. ${ }^{16} \mathrm{He}$ stood out by his numerous papers as well as his prolific work in foreign journals, which was not typical of Serbian legal scholars. ${ }^{17}$ His papers were published in all major languages and they were even translated into Japanese, which is unusual. ${ }^{18}$ In a certain way, this shows how far his reputation extended.

In any case, Živojin Perić saw the breakdown of the Yugoslav state in 1941 and the ensuing Nazi occupation having already attained the respect of his peers for his expertise. However, the attitude toward his political views and activism was significantly different. Even with the flattering comments by J. Prodanović, it would be an understatement to say that he was misunderstood and unaccepted because of his peculiar political ideas. It was noted that many considered him as "rather bizarre." ${ }^{19} \mathrm{In}$ other words, he seemed like an odd person to them. The public even "ridiculed him, often harshly," to quote another contemporary and his student

13 Ibid., 485.

14 More about this in: Popović-Obradović, „Živojin Perić“, 339-344.

15 Three foreign lawyers published their additions to the topic of the role and importance of Živojin Perić for the legal science above all in the journal Legal thought (Pravna misao): Edouard Lambert, „Les services rendus au droit comparé per Jivoin Péritch“, Louis Josserand, „L'idéalisme de Jivoin Péritch“ and René Demogues, „Jivoin Péritch et le roit comparé" (Правна мисао 11-12/1937, 451-482).

16 Arhiv Srbije (Archives of Serbia - AS), Lični fond Živojina Perića (1868-1953), 18901944 (ŽP), biografija.

17 Velizar Mitrović and Mileta Prodanović stressed that Živojin Perić, a speaker of many foreign languages, published a lot in foreign legal journals and that the number of those papers "reaches into the hundreds." According to them, this was "a rare activity" which not only set him apart from other Serbian legal scientists, but also made him "very meritorious for his homeland" in the area of science. The reason for this was that he provided foreign scientists and foreign public with knowledge of the country, its organization and law-making (В. Митровић, „О седамдесетогодишњици др Живојина Перића“, 5; Милета Новаковић, „Рад г. Перића у страним правним књижевностима“, Архив за правне и друштвене науке 1-2/1938, 25-27).

18 Кечкић, Јовановић, „Биографија“, 648.

19 Popović-Obradović, „Živojin Perić“, 335. 
Milan Bartoš. ${ }^{20}$ Because of this, and in order to gain a better understanding of his work under the Nazi occupation, we will focus here only on a certain number of his political ideas and opinions. Namely, as a conservative, when it came to foreign policy, Živojin Perić opposed relying on Russia and was a proponent of Serbia being annexed to Austria-Hungary. According to him, this was the only way to improve Serbia's position in the international community and accomplish its national objectives. During World War I, he lived in Belgrade and cooperated with the Austro-Hungarian occupation government. Even at the end of the war, when it was clear that the world's great powers had allowed for the dissolution of Austria-Hungary, he was still a proponent of preserving the Dual Monarchy. ${ }^{21}$ The public, especially his political opponents, perceived his expression of these kinds of ideas and opinions as "a crazy conviction," "an irrational action," "treason," and "a pathological occurrence." ${ }^{22}$ Unlike others, he did not suffer any sanctions for these attitudes and activism after the war. His behavior during the occupation was disputed occasionally, but he was neither tried nor banned from returning to the school. ${ }^{23}$ This probably had to do with his great scholarly reputation and his personal honesty, as well as the fact that the public had been familiar with his opinions on Serbia's foreign policy for a long time. Many years later, while evaluating this attitude, Dragoljub Jovanović wrote that Perić "was not a bad Serb, but he had singular political and philosophical convictions that bordered on idée fixe." ${ }^{24}$

Although Ž. Perić withdrew from active politics in the interwar period, he remained consistent in many of his convictions; for example, regarding his opinion that Austria-Hungary should not have been dissolved. He proposed the creation of a Danube alliance in its place. He also impugned the Treaty of Versailles, immediately after its ratification, believ-

20 Бартош, „In Memoiriam“, 121.

21 Ž. Perić declined the occupation authority's offer to become mayor of Belgrade, but he did become a member of the Board for Citizens' Relief. He advocated the idea of convening a constituent assembly which would overthrow the existing government on Corfu and create a pro-Austrian government, which would then go on to sign a separate peace treaty (Трговчевић, Научници Србије, 84-88).

22 „Једно издајство“, Правда, 6. 4. 1914, 1; Живојин М. Перић, „Спољашња политика Српске конзервативне странке“, Српски лист (Le Journal Serbe), 28. 9. 1918, 1-2; Трговчевић, Научници Србије, 86.

23 More about this in: Матковић, „Политичка мисао“, 38-43. - Some people were tried after the war, as was the case with Jovan Sjenicki (Јован Сјеницки, Успомене из окупације, (Београд: Народна мисао, 1930)).

24 Драгољуб Јовановић, Медаљони, књига I, (Београд: Службени гласник, 2008), 375. 
ing it harbored the seed of future strife. In a series of texts, he pointed to the weaknesses of the League of Nations in preserving the international order. He also advocated a unified Europe based on a federation, and a Yugoslav federation as its part. ${ }^{25}$ Most of these texts were published in foreign journals and newspapers, but in some domestic ones as well. They were often on the sidelines, and they were also in opposition to the official government policy. ${ }^{26} \mathrm{He}$ was criticized harshly for this. Some of these publications were even banned by censorship, such as his articles in a newspaper called Zeta from Podgorica, which was supposed to publish his article "Living Space" ("Životni prostor"). ${ }^{27}$ It is also important to note that as a legalist, he publicly condemned the conspirators and the assassination of the king [Aleksandar Obrenović] in 1903. He even filed criminal charges against them, which he re-submitted annually so the statute of limitations would not expire. He did this until 1929, when a new criminal law was enacted, which introduced an absolute statute of limitations. ${ }^{28}$ However, regarding the topic at hand, it is important to state that these ideas were not against Germany and its policy. He expressed great understanding for Germany, criticizing the policy of England and the League of Nations, and thereby impugning the provisions of the peace treaty. On the other hand, he did not approve of the means by which Germany was securing its "living space." At the beginning of the war, he fervently advocated the ideas

25 Popović-Obradović, „Živojin Perić“, 335; Живојин Перић, „Животни простор“, Наш поглед на Европу: српски интелектуалци о европиским проблемима између два светска рата, ур. Маринко М. Вучинић, (Београд: Службени гласник, 2013), 131-141. The paper was reprinted from Правна мисао 1940.

26 The Slovene journal Dejane should also be mentioned. It was edited by Edvard Kocbek, $\mathrm{PhD}$, and it wanted to publish Perić's view on the "federal" organization of Yugoslavia and Europe, with which it agreed. The monthly journal Pregled (Overview) from Sarajevo and a weekly paper from Velika Kikinda published a commentary on Perić's article on the pacification of Europe (AS, ŽP 579, Pisma Edvarda Kocbeka Živojinu Periću, 20. 2. 1940 - 2. 1. 1941; AS, ŽP 802, Pisma uredništva Pregleda Živojinu Periću, 3. 7.1940).

27 This was a weekly which had at that point already published Perić's paper on the federal organization of the state of Yugoslavia (AS, ŽP 468, Pisma Jovana P. Vučkovića, urednika Zete, Živojinu Periću, 8. 10. 1939. - 17. 1. 1941). This paper was later published under the same title in the journal called Pravna misao (Legal Thought).

28 Бартош, „In Memoiriam“, 121. - Ž. Perić and his supporters founded the “Society for the Lawful Solution of the Issue of Conspiracy" towards the end of 1905. This organization tried to prove the state's duty to punish the conspirators through legal arguments (Димитрије Ђорђевић, „Сучељавање са Аустро-Угарском“, Историја српског народа, 6-1, (Београд: Српска књижевна задруга, 1994), 140; ПоповићОбрадовић, Парламентаризам, 112). 
of Yugoslav neutrality and good relations with Germany. ${ }^{29}$ These tendencies were a reflection of his pacifist and anti-war ideas.

Without a doubt, with his views and activism thus far, Živojin Perić was quite an acceptable figure for the German occupation government in Serbia. Thus, he was also a welcome and important figure for the Serbian collaborationist administration under occupation, which wanted him in their ranks and on their side. This is how they would strengthen their authority. Živojin Perić received a call for collaboration on May $12^{\text {th }}, 1941$, almost right after the formation of Serbia's first "government" under occupation. He accepted the invitation without hesitation ("gladly"). ${ }^{30}$ From then on until the end of the occupation, he cooperated with and supported the Serbian authorities and their collaboration with the invader in many ways. In addition to participating in expert bodies (councils and committees) of certain ministries, he also gave lectures, published articles in newspapers, and was a member of juries in calls for submissions that pertained to his expertise.

Živojin Perić began his collaboration by working for the newly established Legislative Council within the Ministry of Justice. Not only was he a member of the Council, but he was also its president as of July $25^{\text {th }}$, 1941. He remained at that position until June 1943. ${ }^{31}$ This was an expert body which had the "duty to use its legal expertise to consider and evaluate the drafts of decrees and statutes and give its legal opinion on issues of a legal and legislative nature." ${ }^{32}$ There is not sufficient data about its work. What is known is that its members were pre-war legal experts, like Perić. The council's functioning was based on the Regulation on the Foundation and Operation of the Legislative Council. According to some opinions, this Regulation was "probably" written by Živojin Perić. ${ }^{33}$ Considering his reputation and age at the time, this is most likely true. The Council consisted of sixteen members, appointed by the Minister of Jus-

29 More on this in: Живојин Перић, „Равнотежа сила или Европска савезна држава (еквилибристи или федералисти)“, Наш поглед на Европу, 99-114; The paper was reprinted from Правна мисао, No. 21-22, November-December 1939; Перић, „Животни простор“, 131-141.

30 AS, ŽP 59, Pismo komesara Ministarstva pravde Momčila Jankovića Živojinu Periću, br. 34481, 12. 5. 1941; Ibid., Pismo Živojina Perića Momčilu Jankoviću, komesaru Ministarstva pravde, 14. 5. 1941.

31 AS, ŽP 59, Pismo Živojina Perića Momčilu Jankoviću, komesaru Ministarstva pravde, 14. 5. 1941; Матковић, Политичка мисао, 53.

32 AS, ŽP 59, Pismo komesara Ministarstva pravde Momčila Jankovića Živojinu Periću, br. 34481, 12. 5. 1941.

33 Матковић, Политичка мисао, 53. 
tice, from the ranks of acting or retired university professors, judges, attorneys, and other eminent lawyers. Their service at the Council was of an advisory nature, unpaid and honorary. The Council's engagement was permanent or temporary, as needed. ${ }^{34}$ Apart from Perić, other members of the Council, at least at the beginning, included Đuro Kotur, PhD, deputy commissioner of justice, Dragutin Janković, $\mathrm{PhD}$, university professor and journalist, Adam Lazarević, university professor, Toma Lj. Milosavljević, legislator and attorney, Laza Kostić, PhD, university professor, and Nikolaj Pahorukov, lawyer, former secretary and inspector of the Ministry of Justice..$^{35}$ In essence, the Council was tasked with considering every law and regulation passed under occupation. The Council was to determine whether they were in constitutional or other accordance or regularity with international law or the pre-war legal system. The first session was held as early as May $15^{\text {th }}, 1941 .{ }^{36}$ At least according to the overview of saved minutes, it seems that the Council met almost constantly, especially in the first months of the occupation; and even probably later on, as needed. This made sense, because German occupation meant a new legal and political state in the country. It required the formation of an expert body to provide the Justice Commissioner with opinions on current legal matters. Therefore, Živojin Perić's role in this body, although not publically prominent, was unusually important for the legal operations of not only the domestic authorities, but the occupied society as a whole. This is shown in a short overview of the Council's activities. Ž. Perić and the members of the Council worked, among other things, on the issue of the continuing practice of the State Court for the Protection of the State and the State Prosecutor's Office at that court, the draft of the Regulation on Registering, Determining and Evaluating War Damages, amendments to the regulations on joint-stock companies, the draft on the authorities of the Special Commissioner for the restoration of Smederevo, the draft of the Regulation on the Seizure of Immovable Property of Persons Convicted for Crimes of Communism and Anarchism, the draft of the Regulation on Special Criminal Acts and Direct Court, and others. They were also asked to scrutinize the origin of the property of public servants, members of political bodies, and persons doing business with the state and self-governed bodies, and

34 AS, ŽP 59, Pismo komesara Ministarstva pravde Momčila Jankovića Živojinu Periću, br. 34481, 12. 5. 1941. On this in: Матковић, Политичка мисао, 53-54.

35 AS, ŽP 59, Zapisnici sednica Zakonodavnog saveta 1941.

36 AS, ŽP 59, Obaveštenje Ministarstva pravde Živojinu Periću, br. 34481, 13. 5. 1941. 
deal with issues such as the relationship of the authorities toward the existence and operation of the Serbian Labor Community, etc. ${ }^{37}$

Some issues on which the Council was to give an opinion were particularly important, as they caused disputes among the Council members. At one of the first sessions, the Council considered the issue of the rights of occupation soldiers on the occupied territory of Serbia and the role of the Council of Commissioners. The first issue, about the rights of the occupation army, did not cause any dispute. It was accepted in accordance with the provisions of international conventions. ${ }^{38}$ However, an issue arose among the Council members on whether the Council of Commissioners had the authority to change the existing laws in a situation where the factual authority was in the hands of the occupational force and the Ministerial Council no longer existed. For Perić and the majority of the members, there was no question that it was allowed, because some of the Ministerial Council's jurisdiction was already transferred to the Council of Commissioners. This Council was allowed to do that, as it did, with its regulations, statutes and other ordinances "if public interest so required." However, Dragutin Janković found fault with this and wrote in a separate opinion that the March 27 ${ }^{\text {th }}, 1941$ coup had to be taken into consideration, as it basically altered the constitutional situation, especially regarding the authority of the king. He believed that the coup had "put back into place all the unconstitutionally suspended constitutional regulations, according to Article 116 of the Constitution..." even the articles according to which the legislative authority was held by the king and the people's representatives. ${ }^{39}$ The rest of the Council members, including Živojin Perić, did not share this opinion. However, they never said so openly, but D. Janković's separate opinion and the confirmed views of the majority are enough proof of this.

Ž. Perićs position on the unacceptable nature of the use of force in the change of government had already been known. For him, lawfulness, that is, legality, was above all. It was the red line he would never cross,

37 AS, ŽP 59, Izveštaj o radu Zakonodavnog saveta do 24. 5. 1943.

38 This issue was settled by the IV Convention adopted at the Second Hague Conference of 1907, whose final act was signed by delegates from Germany and Serbia. Article 43 of this convention states: "The authority of the legitimate power having in fact passed into the hands of the occupant, the latter shall take all the measures in his power to restore, and ensure, as far as possible, public order and safety, while respecting, unless absolutely prevented, the laws in force in the country" (AS, ŽP 59, Zapisnik pete sednice Zakonodavnog saveta Ministarstva pravde 26. 5. 1941).

39 AS, ŽP 59, Zapisnik pete sednice Zakonodavnog saveta Ministarstva pravde 26. 5. 1941. 
while violence, which for him included coups, was an act that destroyed legality and led to violence and anarchy. This is why he could never accept or approve the actions of March $27^{\text {th }}, 1941 .^{40}$ He publicly stated his opinion on the topic on multiple occasions, as well as in his private correspondence during the occupation. He believed that the March $27^{\text {th }}$ coup was an act of "feeble-minded and violent policy of the rebels," which would inevitably lead to war. ${ }^{41} \mathrm{He}$ could not understand, as "a Christian pacifist and a Serb," how anyone could dare turn to violence in such a delicate moment for their country. The country "could have stayed neutral and in peace" 42 He wrote: "The feeble-mindedness in politics leads to violence, and violence is by and large a sign of feeble-mindedness." This is why he was taken aback by two of his colleagues, Slobodan Janković and Božidar Boža Marković taking part in the coup. The former became the Vice President and the latter became the Minister of Justice of the putschist government. Both of them were either in their early or mid-eighties. Ž. Perić could not comprehend how both of them could take part in this "political adventure" when they had stayed away from it for so long. He was particularly upset by the fact that, as he saw it, they went against what they had spent years teaching at the university. He wrote with resignation: "Mr. Jovanović taught his students for 40 years that no single person's desire could come above the Constitution, while Mr. Marković taught that a coup was among the most serious of crimes. The fact that the two of them had violated that very same Constitution and Criminal Code, denying their teaching and lectures, was similar to a Christian priest renouncing the Gospel." ${ }^{33} \mathrm{He}$ could find no excuse for such an act, even a year after the fact, except that they both "had to have been FORCED to do so... which, according to positive law and ethics, reduced their responsibility" (original emphasis - N. M.). ${ }^{44}$ He thought similarly about Milan Grol, whom he considered "a Christian and a man of culture." ${ }^{45} \mathrm{He}$ particularly pointed out to their responsibility as lawyers. Legality was at the foundation of the state for Perić, and the coup had brought down the state. The reason that led the rebels itself

40 Arhiv Jugoslavije (Archives of Yugoslavia - AJ), Emigrantska vlada Kraljevine Jugoslavije (103), 158-556, Pismo Živojina Perića jugoslovenskom poslaniku Jurišiću, Oberurnen, Canton Glarus, 27. 8. 1942.

41 Ibid.

42 AJ, 103-88-336, Pismo Živojina Perića jugoslovenskom poslaniku Jurišiću, Oberurnen, Canton Glarus, 19. 9. 1942.

43 AJ, 103-158-556, Pismo Živojina Perića jugoslovenskom poslaniku Jurišiću, Oberurnen, Canton Glarus, 27. 8. 1942.

44 Ibid.

45 Ibid. 
- "the defense of the state" - could not, he indicated, be reason enough for anyone who thought the state was under threat to willfully dismantle the state's Constitution and laws. For him this did not constitute patriotism, but rather the opposite. Patriotism meant taking care of order, work, and law, which had also once been the motto of his Conservative party. ${ }^{46}$

Based on the aforementioned view, Živojin Perić stressed that the new putschist Yugoslav government-in-exile was "purely fictitious, without any real foundation." It did not possess state sovereignty, because it governed "without a state." Similarly, he believed that from the standpoint of internal law, that government was not legal. Created "by means of an upheaval" and formal violation of the Constitution and the Law, it was not to be viewed as a legal government. ${ }^{47}$

He expressed most of these opinions during his stay in Switzerland, at the end of summer and the beginning of autumn of 1942, while he was visiting his daughter. He used these legal arguments to refuse to meet with Yugoslav diplomat Jurišić. He underscored the legal and ethical reasons for this. The ethical reasons were based on the fact that the German authorities had given him and his wife permission to travel to Switzerland "without any conditions." He did not want to abuse this trust by meeting with a representative of the Yugoslav government that was at war with Germany and even "at a vicarious war" with Milan Nedić's government. ${ }^{48}$ This was also the root of his legal reasons, because he was president of the legislative council of the ministry of justice. He was adamant that he was under no legal obligations toward the Yugoslav government, and he did not recognize it as such. The government he recognized was that of Milan Nedić, and he was its member. He was especially offended by the fact that the Yugoslav government had assisted the resistance movement in the country and was against Nedić's government. ${ }^{49}$

Živojin Perić also offered a legal interpretation of Serbia and the government of Milan Nedić. According to him, Serbia "possesses all important elements of a state." He explained this by stating that Serbia's legal relations had remained in power "which would otherwise have been impossible," because "without a state, there are no legal relations." He offered proof that Serbia had its people, its territory, and a government that maintained order, and was well respected. He was, of course, aware that,

46 Живојин Перић, „Српски конзерватизам“, Српски народ, 24. 7. 1943, 10.

47 AJ, 103-88-336, Pismo Živojina Perića jugoslovenskom poslaniku Jurišiću, Oberurnen, Canton Glarus, 19. 9. 1942.

48 Ibid.

49 Ibid. 
under the given circumstances, Serbia had fallen under a special category of state. However, he also believed that Serbia belonged to a type of "autonomous (half-sovereign) state under (German) protectorate, similar to Bohemia and Moravia and Norway," because the German occupation forces had allowed it to honor its own constitution and laws and keep its internal administration, specifically "its own government" (first in the form of Commissioners, and later in the form of real ministers). ${ }^{50}$

Živojin Perić notably criticized the Yugoslav government for staging the coup d'état, "throwing" the country into "misfortune," and leaving the country. ${ }^{51}$ On the other hand, according to Perić, the government of Milan Nedić had managed to gain the trust of the Germans and achieve "BROAD AUTONOMY in governing Serbia." (original emphasis - N. M.) He believed that, "with the help of the occupiers," the government was doing what it could to withstand the occupation with as little damage as possible. ${ }^{52}$ As a rigid legal formalist, Perić refused to acknowledge realistic political circumstances and events.

A similar kind of formalism was present in most of Perić's Council activities. According to certain sources and research, this formalism was slightly mitigated under the pressure of political circumstances. But it was evident, particularly in the cases where he disagreed with the other members. He would emphasize even before examining a bill, that it was important for the Councils member to base their opinions solely on

50 AJ, 103-88-336, Pismo Živojina Perića jugoslovenskom poslanku Jurišiću, Oberurnen, Canton Glarus, 19. 9. 1942. - The Protectorate of Bohemia and Moravia was established in mid-March 1939, after Slovakia seceded from Bohemia and Moravia and declared independence. That is when the German Reich annexed Bohemia and Moravia. Germany divided the annexed territory into two administratively separate territories: those inhabited by the Germans were put under direct German authority, and others inhabited by the Czechs were turned into the Protectorate of Bohemia and Moravia. A German commander was at the head of the protectorate. The Czech president Emil Hácha nominally kept his position which had its name changed in accordance with the changes of legal and political status. However, he held no influence. Unlike the Protectorate of Bohemia and Moravia, Germany allowed Norway to establish its own government, with Vidkun Quisling at its head, who, save for a brief period, held power during the occupation. The king and the government went into exile in Great Britain. More in: Piter Kalvokorezi, Gaj Vint, Totalni rat, (Beograd: Izdavačka radna organizacija "Rad", 1987), 71-72, 96-99; Maks Hejstings, Pakao: svet u ratu 19391945, (Beograd: Laguna, 2013), 31-32, 71-82; Ian Kershaw, Do pakla i natrag: Europa 1914.-1949, (Zagreb: Fraktura, 2017).

51 AJ, 103-158-556, Pismo Živojina Perića jugoslovenskom poslaniku Jurišiću, Oberurnen, Canton Glarus, 27. 8. 1942; AS, 103-88-336, Pismo Živojina Perića jugoslovenskom poslaniku Jurišiću, Oberurnen, Canton Glarus, 19. 9. 1942.

52 AJ, 103-158-556, Pismo Živojina Perića jugoslovenskom poslanku Jurišiću, Oberurnen, Canton Glarus, 27. 8. 1942. 
legal regulations. That meant disregarding all "non-legal arguments," i.e. all political elements from their analysis. Doing so led him to voice a legal opinion different from those of others. Perić firmly believed that the oath of officials in an occupied state, where there was a division of sovereignty between the government of the occupied state and the occupying authority, should not be pledged to any of the sovereigns. According to him, this was to be solved just like in the case of Serbia in World War I. Back then, one would only "pledge" that they would perform the given duty conscientiously, and those who "pledged" were not put in a position where they had to break their oath to any governing party (Serbian or German).$^{53}$ In another instance, not only was he isolated in his views, but he came to blows with the justice minister regarding the decree on the Appropriation of Immovable Property of Persons Convicted for Communism and Anarchism and its repurposing for the settlement of refugees. Ž. Perić pointed out that this was impossible, because in pre-war legislation, there was no existing regulation that would allow it. Certain laws had stipulations regarding compensation, but that was not the same as confiscation. One could, to a certain extent, invoke the Constitution of 1931, which did not stipulate confiscation, but did not prohibit it either. That did not sit right with the justice minister, who asked the Council to draw up the decree, which was something that Perić opposed vehemently. He stressed that the Council had no right to interfere in political matters, which it was planning to do, because although the decree pertained to the Law, its purpose was a political one. Therefore, the Council was only to examine the decree once it was brought to them by the relevant political constituents, and provide its legal assessment. ${ }^{54}$ This matter was debated over the course of several months. According to some researchers' estimates, the decree was in fact drawn up by Perić. ${ }^{55}$ If this is true, then Perić himself abandoned one of his own principles - not to participate in the creation of legal texts with a political agenda. That would mean that this uncompromising formalist stopped being exclusively a legal expert. At the same time, he was becoming a political participant. Pending further research, it is impossible to tell with certainty whether this was really the case. On the other hand, his earlier demeanor and his willingness

53 AS, ŽP 59, Odvojeno mišljenje Živojina Perića o pitanju zakletve činovnika, 10. 6. 1941.

54 AS, ŽP 59, Rasprave povodom nacrta Uredbe o oduzimanju nepokretne imovine licima osuđenim zbog krivičnog dela u cilju komunizma ili anarhije, septembar 1941. 
to do whatever he deemed appropriate and say whatever he believed regardless of the consequences, call for greater caution.

At the end of his term with the Council, Perić accepted the invitation from the Principal Educational Council of the Ministry of Education to assist in the creation of the Serbian Civil Plan. He became a member and president of two committees in the legal area: the Board for Determining Legal Terminology and the Board for Examining the Matter of Language in Laws. ${ }^{56}$ The position had originally been offered to Dragoljub Aranđelović, $\mathrm{PhD}$, but he refused it. ${ }^{57}$ On the other hand, Živojin Perić accepted the position at once, and, according to his written entry, he did so "gladly," just like when he had been approached by the Council. He explained the decision by saying the following: "I believe that in these troubling times for the Serbian people and our Serbian country, it is our Christian and national duty to help alleviate, to the extent possible, the current Serbian fate by means of public service." ${ }^{\prime 8}$ One noted result of such activity by Živojin Petrović is his study "On the Issue Legal Terminology" which was bought by the Ministry of Education and Religion in late 1943. Even though he was supposed to receive a fee for this, he refused to accept it..$^{59}$

During the German occupation, Živojin Perić performed and participated in other activities such as lecturing, serving as a member of judging panels, and writing newspaper articles. Especially notable are the lectures he delivered at the Zbor party rallies ${ }^{60}$ and his taking part in the debates organized by the German Science Institute in Belgrade. ${ }^{61}$ Regardless of the topic, these lectures carried a considerable political weight. There were also other lectures that had primarily legal significance, although one cannot underestimate their political importance. He delivered one such lecture at a gala ceremony honoring the anniversary of the Serbian Civ-

56 AS, ŽP 60, Molba Ministarstva prosvete i vera - Živojinu Periću da uđe u Odbor za pravnu terminologiju i jezik u zakonima, br. 738, 28. 5. 1943.

57 Стојановић, Идеје, политички пројекти и пракса владе Милана Недића, 335.

58 AS, ŽP 60, Pismo Živojina Peića Vladimiru Velmar-Jankoviću, pomoćniku ministra prosvete i vera, 29. 5. 1943.

59 AS, ŽP 381, Pismo Glavnog prosvetnog saveta Živojinu Periću, 31. 1. 1944; AS, ŽP 381, Beleška Živojina Perića od 5. 2. 1944. na pismu Glavnog prosvetnog saveta o otkupljenom elaboratu „O pitanju pravne terminologije“ od 31.1.1944.

60 AS, ŽP 163, Pozivno pismo Milosava Vasiljevića Živojinu Periću da održi predavanje u prostorijama Narodnog pokreta „Zbor“ u Krunskoj ulici, 29. 6. 1943. - The lecture was held on February 3, 1944 (Ibid).

61 AS, ŽP 162, Poziv Nemačkog naučnog instituta u Beogradu Živojinu Periću da učestvuje u debati iz oblasti nemačkog i srpskog prava. - Živojin Perić submitted a paper on the protection of rural property in Serbia (February-March, 1943). 
il Law. Parts of this lecture were also published in the press. ${ }^{62}$ It should also be noted that in mid-1943, Živojin Perić took part in a judging panel for a competition organized by the Srpski narod (Serbian People) newspaper. The competition was supposed to choose the best study on "Peasant-Cooperative Organization of the New Serbian State." ${ }^{63}$ It was a constitutive part of a campaign through which the government of Milan Nedić sought to promote a new concept of organization of a "peasant-cooperative state." This concept proposed that the main role was to be played by the peasantry organized in family cooperatives they had in the past, and it was predicted that those would have great significance in the development of Serbia in the future. ${ }^{64}$ As a connoisseur of the legal history of family cooperatives, Perić simply had to be a member of such a panel. ${ }^{65}$ At the same time, by doing so, he supported the concept of this new organization.

His articles belong to the same group, especially the ones that bore witness to his conservative past. Živojin Perić used the interest in conservatives, which resulted from this new "Serbian path" into the future paved by Milan Nedić. This path meant "work, order and peace, spiritual unity and the return to oneself, to our 'glorious past,' under the guidelines of establishing the New Order in Europe under German dominance." The conservatives of the "glorious past" were seen as role-models and instigators. According to the beliefs of the bearers of the Serbian administration under the occupation, the conservatives, along with others, were supposed to enable Serbian progress in the present and in the future. ${ }^{66}$ Therefore, the Srpski narod newspapers first started publishing articles about famous conservatives, Stojan Novaković and Milutin Garašanin, followed by articles about the Serbian Conservative Party and its ideological and political views. This was intended not only to remind the people about these public figures on their anniversary, but use them as examples of good role-mod-

62 Живојин Перић, „Стогодишњица Српског грађанског законика“, Српски народ, 15. 4. 1944, 6 .

63 „Конкурс 'Српског народа' за најбољу студију о Сељачко-задружној организацији нове српске државе“, Српски народ, 10. 7.1943, 7.

64 More on this in: Наташа Милићевић, „Српско грађанство у окупираној Србији 1941-1944“, (докторска дисертација (Ph.D. paper), Универзитет у Београду, Филозофски факултет, Одељење за историју, 2016), 148-152.

65 The judging panel also consisted of Minister Sapajlaković, PhD, Minister Nedeljković, $\mathrm{PhD}$, Tanasije Mitrović, $\mathrm{PhD}$ and University professor A. Lazarević, $\mathrm{PhD}$ and University professor, engineer Nikola Stanković, engineer Božić Božidar, Damjan Kovačević, a publicist, and Miloš Milošević, a journalist. („Конкурс 'Српског народа' за најбољу студију о Сељачко-задружној организацији нове српске државе“, Српски народ, 10. 7. 1943, 7).

66 More on this in: Милићевић, „Српско грађанство“, 134. 
els. ${ }^{67}$ Perić also rode the wave of the restoration of examples from the "glorious past," and in his articles he talked about the conservatives, their history, ideological principles, and their political aspirations. He paid special attention to conservative views on the matter of government organization. The Srpski narod published his article in four installments, which was almost a small study on its own. ${ }^{68}$ The principles of the Conservative Party, "Order, Work, and Legality," nearly overlapped with those of Nedić's government - "Order and Work." ${ }^{\prime 9}$ This was not only a renewal of Serbian conservative views, but it also illustrated Perić's beliefs regarding interwar Europe, the League of Nations, and the policy of Great Britain. Perić wrote numerous articles where he talked about the wrong policy of Great Britain. He laid the blame for the outbreak of the war solely on Great Britain. According to him, due to its selfish interest, Great Britain prevented the organization of Europe on a federal basis. Perić stressed that, for Europe to unite, the French and the German people needed to make peace and cooperate. It was the English that were a major hurdle and did not allow it. At the same time, he was offering proof of great flaws and fallacies of democratic countries. ${ }^{70}$ Conversely, it seemed to him that with Germany they were entering a new era - an era of achieving his ideas of Europe united through the League of European States, where Germany would dominate, and where peace, justice, equality and balance would finally be established. Because of the outcome of World War II, Živojin Perić realized his ideas could not be achieved. At the end of the war, he left Serbia and spent the rest of his life with his daughter in Switzerland. He knew that for him and anyone who had chosen to cooperate with the occupation forces, staying in the country meant not only a new personal and family drama, but almost certain death. He died in 1953, having reached old age. He never got the opportunity to witness at least a partial achievement of some of his ideas, perhaps not in the form he had envisioned them, but certainly conceivable through the creation of the European Union.

67 „Значај конзервативне мисли“, Српски народ, 13. 3. 1943, 10

68 Живојин Перић, „Српски конзервативизам“, Српски народ, 24. 7. 1943, 9-10; Живојин Перић, „Организација законодавне власти. Схватање српских конзервативаца", Српски народ: 16. 10. 1943, 9; 18. 12. 1943, 10, 13; 1. 4. 1944, 8; 8. 4. 1944, 8.

69 Живојин Перић, „Српски конзервативизам“, Српски народ, 24. 7. 1943, 9.

70 Живојин Перић, „О демократији“, Српски народ, 21. 8. 1943, 8; Живојин Перић, „Међународно право, демократија и Европа,“ Српски народ, 19. 2. 1944, 4; Живојин Перић, „Енглеска према Европи“, Српски народ, 8. 7. 1944, 1-2. 
To conclude, Živojin Perić belonged to a small circle of pre-war Serbian intellectuals who consciously chose a strategy of cooperation, i.e. collaboration under Nazi occupation. Just like with the Austro-Hungarian occupation, his collaboration was voluntary and an expression of his views regarding Serbia's national interests. According to available sources, he received no fee or awards for this. That is what set him apart from other intellectuals who supported cooperation with the occupying powers. In fact, his engagement and views under Nazi occupation were a logical and natural extension of his earlier views, beliefs, and activities. It seemed that, for the first time, his views and ideas, although in specific circumstances of war and occupation, became part of a broader stream of political thought of his time. It even seemed that they were becoming a reality. However, generally speaking, Živojin Perić remained in the minority against the mainstream of the Serbian ideological-political thought. The end of the war and the defeat of the supporters of collaboration and the politics of Milan Nedić was a testimony to that fact.

\section{Summary}

Živojin Perić was a unique figure in the history of Serbia, primarily its intellectual history of the first half of the $20^{\text {th }}$ century. He stood out with his original and, in many ways, daring political views and activities. That often meant he was out of and against the mainstream of Serbian politics of his time. During the Nazi occupation of Serbia, Živojin Perić was in Belgrade, just as he was during the Austro-Hungarian occupation in World War I. As in the case of the first occupation of Serbia, he soon started cooperating with the Germans and the Serbian authorities under occupation. He belonged to a small circle of pre-war Serbian intellectuals who consciously chose a strategy of cooperation, i.e. collaboration under Nazi occupation. The strategy entailed versatile cooperation with and support of the Serbian authorities, from participating in expert bodies and ministry committees, lectures and memberships in judging panels, to writing newspaper articles. His participation in the Legislative Council of the Ministry of Justice is especially significant. This was important for the legal functioning of not only the Serbian authorities, but also Serbian society under occupation. According to available sources, he refused any kind of fees for his work under occupation. This again is what set him apart from other intellectuals of the time who had opted for the strategy of collaboration. Research has shown that Perić's engagement and views under 
Nazi occupation were a logical and natural extension of his earlier views, beliefs, and activities. It should be noted that he was an Austrophile and a Germanophile. This can be said to have been a constant in Perić's political thought, one that was not even shaken by two world wars. He believed that neither Russia nor England were countries that Serbia, i.e. Yugoslavia, should be leaning on in its politics. He believed that those countries should be Austro-Hungary in the first place, and then Germany. His second peculiarity was his extremely critical stance on Yugoslavia from the very beginning, from the time of the pro-Yugoslav euphoria in World War I. He also insisted on a federal organization of Yugoslavia from its inception. He was especially known for his struggle for strict legality, which was present ever since he had started his engagement and work in the public sphere. This led him to oppose the rebellion of March 27 1941. Perić believed that there was no state without legality, and that the March 27 coup had subverted this. And not only that, but the coup led to war, which he, being a pacifist, opposed very strongly. That is why he did not recognize the putschist government of the Kingdom of Yugoslavia as legal nor as his own. Instead, he supported the government of Milan Nedić. Moreover, it seemed that his interwar ideas of a League of European States, even if under German domination, were becoming a reality. However, the outcome of World War II dissuaded him from that. The outcome made him leave the country and spend his last years as an emigrant in Switzerland.

\section{Sources and Literature}

- $\quad$ Arhiv Jugoslavije. Fond 103, Emigrantska vlada Kraljevine Jugoslavije.

- $\quad$ Arhiv Srbije. Lični fond Živojina Perića (1868-1953), 1890-1944.

- Demogues, René. „Jivoin Péritch et le roit comparé“. Pravna misao 1112/1937, 480-482.

- Jovanović, Dragoljub. Medaljoni, knjiga I. Beograd: Službeni glasnik, 2008. (cyrillic)

- Kečkić, Dr. Drag. Bl., Živ. P. Jovanović. „Biografija i bibliografija Živojina Perića“. Pravna misao 11-12/1937, 621-649. (cyrillic)

- Lambert, Edouard. „Les services rendus au droit comparé per Jivoin Péritch“. Правна мисао 11-12/1937, 451-470.

- Josserand, Louis. „L'idéalisme de Jivoin Péritch“. Pravna misao 11-12/1937, 471-479.

- Jovanović, Slobodan. „Živojin Perić o vladalačkoj vlasti“. Arhiv za pravne $i$ društvene nauke 1-2/1938, 6-10. (cyrillic) 
- $\quad$ Mitrović, Velizar. „O sedamdesetogodišljici dr Živojina Perića, redovnog profesora Pravnog fakulteta“. Arhiv za pravne i društvene nauke 1-2/1938, 3-5. (cyrillic)

- $\quad$ Novaković, Mileta. „Rad g. Perića u stranim pravnim književnostima“. Arhiv za pravne i društvene nauke 1-2/1938, 25-27. (cyrillic)

- $\quad$ Perić, Živojin. „Životni prostor“. Naš pogled na Evropu: srpski intelektualci o evropiskim problemima između dva svetska rata, prir. Marinko M. Vučinić, 131-141. Beograd: Službeni glasnik, 2013. (cyrillic)

- $\quad$ Perić, Živojin. „Ravnoteža sila ili Evropska savezna država (ekvilibristi ili federalisti)“. Naš pogled na Evropu: srpski intelektualci o evropiskim problemima između dva svetska rata, prir. Marinko M. Vučinić, 99-114. Beograd: Službeni glasnik, 2013. (cyrillic)

- Prodanović, Jaša M. „Politika Živojina Perića“. Pravna misao 11-12/1937, 483-485. (cyrillic)

- $\quad$ Sjenicki, Jovan. Uspomene iz okupacije. Beograd: Narodna misao, 1930. (cyrillic)

- $\quad$ Spasojević, Živojin. „Živojin Perić kao civilista“. Arhiv za pravne i društvene nauke 1-2/1938, 10-16. (cyrillic)

- $\quad$ Srpski civilni/kulturni plan vlade Milana Nedića, prir. Aleksandar Stojanović. Beograd: INIS, 2012. (cyrillic)

- $\quad$ Antonić, Slobodan. „Slika jednog doba“. Srbi 1903-1914: Istorija ideja, prir. Miloš Ković, 763-850. Beograd: Clio, 2015. (cyrillic)

- $\quad$ Bartoš, Milan. „In Memoiriam: Živojin M. Perić (1868-1953)“. Anali Pravnog fakulteta u Beogradu, januar-mart 1954, 118-122. (cyrillic)

- Božić, Marko. „Zadruga kao sudbina: Živojin Perić od Stublina do Beograda i opet nazad“. U: Živojin Perić, Zadružno pravo po Građanskom zakoniku Kraljevine Srbije, 15-21. Beograd: Srpsko advokatsko društvo, JP „Službeni glasnik", 2017. (cyrillic)

- $\quad$ Bondžić, Dragomir. Beogradski univerzitet 1944-1952. Beograd: ISI, 2004.

- Bondžić, Dragomir. „Živojin M. Perić“. Srpski biografski rečnik (mnsc). (cyrillic)

- $\quad$ Vojvodić, Mihailo. Stojan Novaković u službi nacionalnih i državnih interesa. Beograd: Srpska književna zadruga, 2012. (cyrillic)

- Ćeranić, Jelena. „Ideja Evropskog državnog saveza u delima profesora Živojina M. Perića“. Aktuelna pitanja savremenog zakonodavstva, zbornik radova sa Savetovanja pravnika 12-16. jun 2013, Budva, 235-249. Beograd: Savez udruženja pravnika Republike Srbije i Republike Srpske, 2013.

- Delibašić, Tomica. „Osvrt na misao Živojina Perića, klasika prava“. Pravni život 12/2013, 503-516.

- $\quad$ Đorđević, Dimitrije. „Sučeljavanje sa Austro-Ugarskom“. Istorija srpskog naroda, 6-1, 135-173. Beograd: Srpska književna zadruga, 1994. (cyrillic) Hejstings, Maks. Pakao: svet u ratu 1939-1945. Beograd: Laguna, 2013. 
- $\quad$ Kalvokorezi, Piter, Gaj Vint. Totalni rat. Beograd: Izdavačka radna organizacija „Rad“, 1987.

- Kandić, Ljubica, Jelena Danilović. Istorija Pravnog fakulteta u Beogradu 1808-1905, prva knjiga. Beograd: Zavod za udžbenike i nastavna sredstva, 1997. (cyrillic)

- Kandić, Ljubica. Istorija Pravnog fakulteta u Beogradu 1905-1941, druga knjiga, tom I-II. Beograd: Zavod za udžbenike i nastavna sredstva, 2002. (cyrillic)

- $\quad$ Kandić, Ljubica. Istorija Pravnog fakulteta u Beogradu 1941-1945, knj. 3. Beograd, 2005. (cyrillic)

- $\quad$ Kershaw, Ian. Do pakla i natrag: Europa 1914.-1949. Zagreb: Fraktura, 2017.

- Ković, Miloš. „Liberalizam“. Srbi 1903-1914: Istorija ideja, prir. Miloš Ković, 153-201. Beograd: Clio, 2015. (cyrillic)

- $\quad$ Ković, Miloš. „Nacionalizam“. Srbi 1903-1914: Istorija ideja, prir. Miloš Ković, 202-269. Beograd: Clio, 2015, (cyrillic)

- Janićijević, Milosav. Stvaralačka inteligencija međuratne Jugoslavije. Beograd: Institut društvenih nauka - Centar za sociološka istraživanja, 1984.

- Matković, Velimir. „Politička misao Živojina Perića“. Magistarski rad, Univerzitet u Beogradu, Pravni fakultet, Beograd 2013. (cyrillic)

- $\quad$ Milićević, Nataša. „Srpsko građanstvo u okupiranoj Srbiji 1941-1944“. Doktorska disertacija, Univerzitet u Beogradu, Filozofski fakultet, Odeljenje za istoriju, 2016. (cyrillic)

- Miljković, Aleksandar. „Shvatnje Živojina Perića o patrijahalnim porodičnim zadrugama“. Sto pedest godina od donošenja Srpskog građanskog zakonika (1844-1994): zbornik radova sa naučnog skupa održanog 23. i 24. maja 1994, ur. Miodrag Jovičić, 351-359. Beograd: SANU, 1996. (cyrillic)

- Miljković, Aleksandar. „Pogledi Živojina M. Perića na porodičnu zadrugu u Srbiji: prilog kritici Perićevog shvatanja porodične zadruge kao komunističke ustanove“. Anali Pravnog fakulteta u Beogradu 1/2005, 93-112. (cyrillic)

- Mitrović, Andrej. „Nadrastanje poraza i podela“. Istorija srpskog naroda VI-2, 107-254. Beograd: Srpska književna zadruga, 1994. (cyrillic)

- Mitrović, Andrej. Srbija u Prvom svetskom ratu. Beograd: Srpska književna zadruga, 1984. (cyrillic)

- Mladenović, Božica B. Grad u austrougarskoj okupacionoj zoni u Srbiji od 1916. do 1918. godine. Beograd: Čigoja štampa, 2000. (cyrillic)

- Nadoveza, Branko. Politička misao Živojina Perića. Beograd: Institut za političke studije, 2005. (cyrillic)

- $\quad$ Perović, Latinka. Dominantna i neželjena elita. Beleške o intelektualnoj i političkoj eliti u Srbiji XX-XXI vek. Beograd: Dan Graf, Novi Sad: Javna medijska ustanova Radio-televizija Vojvodine, 2015.

- Perović, Slobodan. „Delo Živojina Perića - paradigma kulture prava“. Pravni život, br. 9-10/1993, VII-XX. 
- $\quad$ Perović, Slobodan. „Živojin Perić - život i delo“. Pravni život 1/1987, 111124.

- $\quad$ Popović-Obradović, Olga. „Živojin Perić između liberalizma i konzervativizma“. Liberalna misao u Srbiji. Prilozi istoriji liberalizma od kraja XVIII do sredine XX veka, ur. prof. dr Jovica Trkulja, prof. dr Dragoljub Popović, 317346. Beograd: Centar za unapređivanje pravnih studija, Friedrich Naumann Stiftung, 2001.

- Popović-Obradović, Olga. Parlamentarizam u Srbiji 1903-1914. Beograd: Javno preduzeće Službeni lis SRJ, 1998. (cyrillic)

- $\quad$ Simić, Miroljub. „Teorija tumačenja prava Živojina M. Perića“. Zbornik radova Pravnog fakulteta u Nišu 19/1979, 319-336.

- Simić, Miroljub. „Teorija tumačenja prava Živojina M. Perića (nastavak)“. Zbornik radova Pravnog fakulteta u Nišu 19/1980, 369-380.

- $\quad$ Stojanović, Aleksandar. Ideje, politički projekti i praksa vlade Milana Nedića. Beograd: INIS, 2015. (cyrillic)

- $\quad$ Trgovčević, Ljubinka. Naučnici Srbije i stvaranje jugoslovenske države 19141920. Beograd: Narodna knjiga i Srpska književna zadruga, 1987. (cyrillic)

- Trkulja, Jovica. „Ispravljanje nepravde. Povodom 140. godišnjice rođenja Živojina Perića“. Hereticus 3-4/2008, 319-328.

- Trkulja, Jovica. „Političke studije Živojina Perića“. Naučno nasleđe Pravnog fakulteta u Beogradu 1841-1941. Referati sa simpozijuma održanog 9. i 10. aprila 1992, ur. Stevan Vračar, Jovica Trkulja, 399-409. Beograd: Pravni fakultet u Beogradu, 1994. (cyrillic)

- Pravda 1914. (cyrillic)

- $\quad$ Srpski list (Le Journal Serbe) 1918. (cyrillic)

- $\quad$ Srpski narod 1943-1944. (cyrillic) 


\title{
Резиме
}

Наташа Милићевић

\section{Увек у мањини: Живојин Перић У окупираној Србији 1941-1944.}

\begin{abstract}
Апстракт: Рад анализира активност и погледе др Живојина Перића, једног од истакнутих интелектуалаца предратне Југославије, током нацистичке окупације Србије. Иако је акценат стављен на његове ратне погледе и ставове, нису заобиђени, ради указивања на континуитет или дисконтинуитет, ни његови доратни ставови и уверења о разним политичким и друштвеним питањима.
\end{abstract}

Кључне речи: Србија, Други светски рат, немачка окупација, Живојин Перић, колаборација

Живојин Перић је био особена појава српске, пре свега интелектуалне историје прве половине 20. века. Истицао се једном оригиналном и у много чему смелом идејно-политичком мишљу и активношћу. Често га је она водила изван и против главних токова политичке мисли његовог времена. Живојин Перић је нацистичку окупацију Србије провео, као и аустроугарску у Првом свеском рату, у Београду. Као и у случају прве окупације Србије, убрзо је успоставио сарадњу са немачким и српским властима под окупацијом. Он је припадао невеликом кругу предратних интелектуалаца који су свесно и добровољно одабрали стратегију колаборације под окупацијом, која је подразумевала разноврсну сарадњу и подршку српским властима, почев од чланства у стручним телима и одборима министарства преко предавања и чланства у жиријима конкурса до писања чланака у новинама. Специфичну тежину имало је учешће у Законодавном савету Министарства правде. Оно је било важно за правно функционисање не само српске власти већ и српског друштва под окупацијом. Изгледа да је, како извори показују, одбио сваки хонорар за свој рад под окупацијом. То га је опет издвојило од осталих интелектулаца тог времена који су одабрали стратегију колаборације. Истраживање је показало да су ангажованост и погледи Живојина Перића под окупацијом били логичан, природан наставак ранијих схватања 
и уверења, али и активности. Међу њима ваља истаћи његово аустрофилство, односно греманофилство. То је, може се рећи, константа у Перићевој мисли, коју чак нису поколебала ни два светска рата. Сматрао је да Русија а ни и Енглеска нису земље на које Србија, односно Југославија треба да се ослањају у својој политици. То су по њему били прво Аустроугарска а онда Немачка. Друга особеност је веома критичан став према Југославији и то од самог почетка, од времена пројугословенске еуфорије у Првом светском рату. Инсистирао је од самог почетка и на федералном државном уређењу Југославије. Посебно питање представљала је његова борба за строгу легалност тј. законитост, присутна од почетка јавног ангажовања и рада. Она га је одвела међу противнике 27. марта 1941. Перић је сматрао да без легалности нема државе, а пучем од 27. марта она је била срушена. И не само то. Пуч је водио у рат, коме се он, као пацифиста, оштро противио. Због тога пучистичку владу Краљевине Југославије није сматрао ни легалном а ни својом владом, већ је то била влада Милана Недића. Осим тога, изгледало је и да његове међуратне идеје о савезу европских држава, додуше под немачком доминацијом, постају стварност. У то га је, међутим, разуверио исход Другог светског рата. Исход га је приморао и да напусти земљу и последње године проведе као емигрант у Швајцарској. 